clear solid cakes of ice from any of the natural waters found in the United States, without first distilling them.

\section{Fuel and Oil used at High Speeds}

There is now a great demand for special fuels and lubricants to meet the needs of engines for fast transportation. Science Service, Washington, D.C., has issued an interesting report of an address by Dr. Gustav Fgloff, director of research of the Universal Oil Products Co., on this subject. Ho said that the lubricating oils made from petroleum a few years ago would decompose and vanish if used in modern engines, leaving the metal parts to fuse together in hopeless ruin. The strain put upon the lubricunt at 70 miles per hour is far greater than at the 35-milo rate of ten years ago. In the case of aoroplanes, the difficulty of keeping a strong film of oil between the moving metal parts at 200 miles an hour is enormous. Lubricating oils are now refined by distillation under vacuum or by using solvents which dissolve tho desirable parts from the undesirable. Paraffin wax is separated from lubricating oils at refrigeration tomperatures so low as $-60^{\circ} \mathrm{F}$., or inhibitors are used to prevent its crystalline formation. Gasoline is no longer produced from crude oil by distillation, but is manufactured scientifically from parts of the crude oil.

\section{An Inquiry into Cancer of the Skin}

In a recently issued report, Mr. (iretta M. Thomas records the results of an inquiry undertaken at the instance of the Yorkshire Council of the British Empire Cancer Campaign under the direction of the Faculty of the General Infirmary at Leeds (Reps. on Pub. Health and Ved. Subjects, No. 70. H.M. Stationery Office. Price 2s. od. net). One of the objectives of the inquiry was an attempt to ascertain whether environmental conditions associated with occupation or industry, other than those already recognised, are conducive to skin cancer; but no definite indications on this point were elicited. Many instances of tho supervention of skin cancer upon a previously existing non-malignant lesion, such as lupus, were met with, and sccond cancers of the skin were found occasionally to occur in those who had suffered from the first growth at least six years previously. No facts were met with in explanation of the difference in incidence of lip cancer in the two sexes, which is considorably higher in malos.

\section{Sterilisation of the Unfit}

IT is announced that the Departmental Committeo on Sterilisation has now finished hearing evidence but it is still awaiting tho completion of certain returns which local authorities have been asked to furnish. The Committee has now adjourned for a short time, but will meet again in Septembor to sottle the report, which it is hoped to complete by the end of October. A preliminary draft of the report is in course of preparation, but it has not yet been considered by the Committee, and statements purporting to fore. cast the Committee's recommendations are wholly unfounded.

\section{Announcements}

WE regret to announce the following deaths:Mr. W. J. Lewis Abbott, known for his contributions to the prohistory of England, and collection of flint implements, aged eighty years; Dr. M. O. Malte, chief botanist in the National Herbarium, Victoria Memorial Museum, Ottawa, Canada, and prineipal research botanist of the Federal (Kovernment, known for his work on the flora of Canada, aged fifty-three years ; Mr. Edward Roberts, I.S.O., secretary of the Tide Committee of the British Association in 1868-75, a pioneer in the practical development of tidal prediction, on August 4, aged eighty-seven ycars; Mr. H. F. Tagg, for nearly forty years keeper of the museum at the Royal Botanic Garden, Wdinburgh, on August 9.

THe summer number of the Fight Against Disease, the quarterly journal of the Research Defence Society, contains among other matter the annual report of the Committee and report of the annual general meeting, und the seventh Stephen Paget memorial lecture, which was delivered by Maj.-(ken. Sir Leonard Rogers (see Natike of July 8, p. 57).

The Ministry of Health has issued a circular (No. 1345. H.M. Stationery Office. Price 2d. net) containing the descriptions, with reproductions, of the certificates, labels, marks and stamps which will be recognised from September $l$ as official certificates for the purposes of the Public Health (Imported Food) Regulations, 1925, and the Public Health (Imported Food) Amendment Regulations, 1933.

WE have received the first number of a new quarterly journal, entitled Le Travail Humain, edited by MM. J.-M. Lahy, H. Laugier, and R. Bonnardel, and published by the Conservatoire National de's Arts et Métiers (292, Rue Suint-Martin, Paris III"). It deals with physiology, psychology, biometry, and hygiene in relation to industry, und contains original articles and a summary of current literature. The annual subscription price (foreign) is $130 \mathrm{fr}$.

Applications are invited for the following appointments, on or before the dates mentioned:-An assistant lecturer in mathematics at the Imporial College of Science and Technology, South Kensington, S.W.7-Tho Secretary (Aug. 25). An inspector for the purposes of the Diserses of Animals Acts, 1894 1927..-The Secrotary, Ministry of Agriculture and Fisheries, 10, Whitehall Place, London, S.W.1 (Aug. 28). A principal of the Farm Institute, Sparsholt, near Winchester-The Agricultural Organiser, 82, High Street, Winchester (Aug. 28). A lecturer in zoology at MeGill University, Montreal-The Secretary (Sept. 9). An inspector of explosives to the Home Office--The Private Secrotary, Home Office, Whitehall, S.W.1 (Sept. 15). A conservator of the Museum and a director of research at the Royal College of Surgeons of Fingland-The Secretary (Oct. 7). 